\title{
DOUTRINA
}

\section{DA SUPREMACIA DO INTERESSE PÚBLICO AO DEVER DE PROPORCIONALIDADE: UM NOVO PARADIGMA PARA O DIREITO ADMINISTRATIVO*}

GuSTAVO BINENBOJM**

I. A outra história do direito administrativo: do pecado autoritário original à constituição de uma dogmática a serviço dos donos do poder. II. A crise dos paradigmas do direito administrativo e a emergência de um novo modelo teórico. III. Construção e Desconstrução do Princípio da Supremacia do Interesse Público. III.I. O principio da supremacia do interesse público, segundo a doutrina brasileira. III.2. A desconstrução do princípio da supremacia do interesse público. IV. A Constitucionalização do Direito Administrativo e a Formulação de um Novo Paradigma da Administração Pública. IV.1. O dever de proporcionalidade como fundamento e técnica da decisão administrativa. IV.2. A Proporcionalidade e as Normas Instituidoras de Privilégios para a Administração. IV.3. A Proporcionalidade e as Normas Restritivas de Direitos Individuais. V. Conclusão.

\section{A outra história do direito administrativo: do pecado autoritário original à} constituição de uma dogmática a serviço dos donos do poder

Narra a história oficial que o direito administrativo nasceu da subordinação do poder à lei e da correlativa definição de uma pauta de direitos individuais que

* O presente artigo é fruto, em parte, das reflexões e discussões que mantive com meus alunos Alice Voronoff, Cláudia Türner, Isabel Picot, Fabio Macedo, Mateus Queiroz e Paola Dias, do Grupo de Pesquisa em Direito Administrativo que coordeno na Faculdade de Direito da UERJ. Meu sentimento para com eles é de co-autoria, embora tudo que aqui se encontre escrito seja de minha integral e exclusiva responsabilidade.

** Professor de Direito Administrativo da Faculdade de Direito da UERJ. Professor do Curso de Pós-Graduação da Fundaçāo Getúlio Vargas -- FGV. Profes:sor da Escola da Magistratura do Estado do Rio de Janeiro - EMERJ. Master of Laws, Yale Law School. Mestre e Doutorando em Direito Público pela Faculdade de Direito da UERJ. Procurador do Estado, advogado e parecerista no Rio de Janeiro. 
passavam a vincular a Administração Pública. ' Essa noção garantística do direito administrativo, que se teria formado a partir do momento em que o poder aceita submeter-se ao direito ${ }^{2} \mathrm{e}$, por via reflexa, aos direitos dos cidadãos, alimentou o mito de uma origem milagrosa $a^{3}$ e de categorias jurídicas exorbitantes do direito comum cuja justificativa teórica seria a de melhor atender à consecução do interesse público. $^{4}$

A cada ano, repetimo-nos a nós mesmos e a nossos alunos a mesma fábula mistificadora: a de que a certidão de nascimento do direito administrativo foi a Loi 28 Pluviose do ano VIII. editada em 1800, nos albores da Revolução Francesa, organizando e limitando externamente a Administração Pública. Tal lei simbolizaria a superação da estrutura de poder do Antigo Regime fundada, não no direito, mas na vontade do soberano (quod regi placuit lex est). A mesma lei que organiza a estrutura da burocracia estatal e define suas funções operaria como instrumento de contenção do seu poder, agora subordinado à vontade heterônoma do Poder Legislativo.

Dentro da lógica da separação dos poderes, ao Parlamento, como veículo de expressão da vontade geral, caberia o primado na elaboração das normas jurídicas, que não só limitariam como preordenariam a atuação dos órgãos administrativos. À Administração restaria, assim, uma função meramente executiva, de cumprimento mecânico da vontade já manifestada pelo legislador. Surge, destarte, a idéia da legalidade como vinculação positiva à lei: se aos particulares, em prestígio e valorização de sua autonomia pública e privada, é permitido fazer tudo aquilo que não lhes for vedado pela lei, à Administração Pública cabe agir tão-somente de acordo com o que lei prescreve ou faculta. Esta descrição romântica do fenômeno de surgimento do direito administrativo é acolhida por ninguém menos que Caio Tácito. Veja-se:

"O episódio central da história administrativa do século XIX é a subordinação do Estado ao regime de legalidade. A lei, como expressão da vontade

1 V., por todos, Caio Tácito, Evolução Histórica do Direito Administrativo, in Temas de Direito Público, vol. I, 1997, p. 2.

2 Neste sentido, Diogo Freitas do Amaral, Curso de Direito Administrativo, vol. I, 1994, p. 148.

3 Textualmente, esta é a expressão utilizada por Prosper Weil para explicar o surgimento do direito administrativo. V. O Direito Administrativo, 1977, p. 7-10: "A própria existência de um direito administrativo é em alguma medida fruto de um milagre. $O$ direito que rege a actividade dos particulares é imposto a estes de fora e o respeito pelos direitos e obrigações que ele comporta encontra-se colocado sob a autoridade e a sanção de um poder exterior e superior: o do Estado. Mas causa admiração que o próprio Estado se considere ligado (vinculado) pelo direito. (...) Não esqueçamos, aliás, as liçōes da história: a conquista do Estado pelo direito é relativamente recente e não está ainda terminada por toda a parte. (...) Fruto de um milagre, o direito administrativo só subsiste, de resto, por um prodígio a cada dia renovado. (...) Para que o milagre se realize e se prolongue devem ser preenchidas diversas condições que dependem da forma do Estado, do prestígio do direito e dos juízes, do espírito do tempo."

4 Neste sentido, Celso Antônio Bandeira de Melo, Curso de Direito Administrativo, 1999, p. 56-8. 
coletiva, incide tanto sobre os individuos como sobre as autoridades públicas. A liberdade administrativa cessa onde principia a vedação legal. $O$ Executivo opera dentro dos limites traçados pelo Legislativo, sob a vigilância do Judiciário." 5

Tal história seria esclarecedora, e até mesmo louvável, não fosse falsa. Descendo-se da superfície dos exemplos genéricos às profundezas dos detalhes, verifica-se que a história da origem e do desenvolvimento do direito administrativo é bem outra. E o diabo, como se sabe, está nos detalhes. A associação da gênese do direito administrativo ao advento do Estado de direito e do princípio da separação de poderes na França pós-revolucionária caracteriza erro histórico e reprodução acrítica de um discurso de embotamento da realidade repetido por sucessivas gerações, constituindo aquilo que Paulo Otero denominou ilusão garantística da gênese.$^{6} \mathrm{O}$ surgimento do direito administrativo, e de suas categorias jurídicas peculiares (supremacia do interesse público, prerrogativas da Administração, discricionariedade, insindicabilidade do mérito administrativo, dentre outras), representou antes uma forma de reprodução e sobrevivência das práticas administrativas do Antigo Regime que a sua superação. A juridicização embrionária da Administração Pública não logrou subordiná-la ao direito; ao revés, serviu-lhe apenas de revestimento e aparato retórico para sua perpetuação fora da esfera de controle dos cidadãos.

O direito administrativo não surgiu da submissão do Estado à vontade heterônoma do legislador. Antes, pelo contrário, a formulação de novos princípios gerais e novas regras jurídicas pelo Conseil d'État em França, que tornaram viáveis soluções diversas das que resultariam da aplicação mecanicista do direito civil aos casos envolvendo a Administração Pública, só foi possível em virtude da postura ativista e insubmissa daquele órgão administrativo à vontade do Parlamento. ${ }^{7}$ A conhecida origem pretoriana do direito administrativo, como construção jurisprudencial do Conselho de Estado derrogatória do direito comum, traz em si esta contradição: a criação de um direito especial da Administração Pública resultou não da vontade geral, expressa pelo Legislativo, mas de decisão autovinculativa do próprio Executivo. $^{8}$

Assim, como assinala Paulo Otero, "a idéia clássica de que a Revolução Francesa comportou a instauração do princípio da legalidade administrativa, tornando o

5 V. Caio Tácito, op. cit., p. 2:

6 V. Paulo Otero, Legalidade e Administração Pública - O Sentido da Vinculação Administrativa à Juridicidade, 2003, p. 271.

7 Neste sentido, Pierre Delvolvé, Paradoxes du (ou paradoxes sur le) principe de séparation des autorités administrative et judiciaire, in Mélanges René Chapus - Droit Administratif, 1992, p. 144.

8 Vale lembrar que o sistema de contencioso administrativo francês sempre reservou ao Poder Executivo a última palavra sobre a competência do Conselho de Estado, criando-se, por via indireta, uma forma sui generis de o Poder Executivo se substituir ao Poder Legislativo na criação do direito especial da Administração Pública. Neste sentido, v. Maria da Glória Ferreira Pinto Dias Garcia, Da Justiça Administrativa em Portugal - Sua Origem e Evolução, 1994, p. 315-6. 
Executivo subordinado à vontade do Parlamento expressa através da lei, assenta num nilto repetido por sucessivas gerações: a criação do direito administrativo pelo Conseil d'État, passando a Administração Pública a pautar-se por normas diferentes daquelas que regulavam a actividade jurídico-privada, não foi um produto da vontade da lei, antes se configura como uma intervenção decisória autovinculativa do Executivo sob proposta do Conseil d'État." ${ }^{9}$

Note-se que tal circunstância histórica subverte, a um só golpe, os dois postulados básicos do Estado de Direito em sua origem liberal: o principio da legalidade e o princípio da separação de poderes. De fato, a atribuição do poder legislativo em matéria administrativa à jurisdição administrativa não se coaduna com as noções clássicas de legalidade como submissão à vontade geral expressa na lei (Rousseau) e partilha de funções entre os poderes (Montesquieu). Nenhum cunho garantístico dos direitos individuais se pode esperar de uma Administração Pública que edita suas próprias normas jurídicas e julga soberanamente seus litígios com os administrados.

Chega-se, assim, à segunda contradição na gênese do direito administrativo: a criação da jurisdição administrativa. Contrariando a noção intuitiva de que ninguém é bom juiz de si mesmo, a introdução do contencioso administrativo - e conseqüente subtração dos litígios jurídico-administrativos da alçada do Poder Judiciário embora alicerçada formalmente na idéia de que "julgar a Administração ainda é administrar", não teve qualquer conteúdo garantístico, mas antes se baseou na desconfiança dos revolucionários franceses contra os tribunais judiciais, pretendendo impedir que o espírito de hostilidade existente nestes últimos contra a Revolução limitasse a ação das autoridades administrativas revolucionárias. ${ }^{10}$

A invocação do princípio da separação de poderes foi um simples pretexto, mera figura de retórica, visando a atingir o objetivo de alargar a esfera de liberdade decisória da Administração, tornando-a imune a qualquer controle judicial. " Aliás. o modelo de contencioso em que a Administração julgaria a si própria não representou qualquer inovação da Revolução Francesa, sendo, ao revés, uma continuidade daquele vigorante durante o Antigo Regime. ${ }^{12}$ Tal como afirmado por Tocqueville, "nesta matéria encontraríamos a fórmula; ao Antigo Regime pertence a idéia." 13

A institucionalização de tal modelo, e sua surpreendente identidade com a estrutura de poder da monarquia absoluta, revela o quanto o direito administrativo, em seu nascedouro, era alheio a qualquer propósito garantístico. Ao contrário, seu intuito primeiro foi o de diminuir as garantias que os cidadãos teriam caso pudessem submeter o controle da atividade administrativa a um poder equidistante, independente e imparcial - o poder judiciário.

9 Paulo Otero, ob. cit., p. 271.

$10 \mathrm{~V}$., sobre o verdadeiro móvel da criação da jurisdição administrativa, André de Laubadère, Jean-Claude Venezia, Yves Gaudemet, Traité de Droit Administratif, vol. I, 1990, p. 248.

11 No mesmo sentido, Paulo Otero, ob. cit., p. 275.

12 Vasco Pereira da Silva, Para um Contencioso Administrativo dos Particulares - Esboço de uma teoria subjectivista do recurso contencioso de anulação, 1989, p. 27.

13 Alexis de Tocqueville, O Antigo Regime e a Revolução, 1989, p. 64. 
Releva destacar, em reforço ainda maior da idéia, que mesmo no âmbito do Conselho de Estado se desenvolveu uma ampla e intensa jurisprudência sobre os limites da própria jurisdição administrativa, seja através da exclusão de certos atos da esfera de reexame - como os atos de governo e os atos de pura administração — seja com a limitação artificial do espectro de fundamentos do recurso contencioso ou ainda pelo desenvolvimento de uma estrita legitimidade processual ativa. ${ }^{14}$ É já nesse período que se evidencia como nítido propósito do contencioso administrativo a criação de um direito processual administrativo, consagrando inúmeras regras de privilégio em favor da Administração. $O$ velho dogma absolutista da verticalidade das relações entre o soberano e seus súditos serviria para justificar, sob o manto da supremacia do interesse público sobre os interesses dos particulares, a quebra de isonomia. E nem se diga que este estatuto especial da Fazenda Pública se limitou historicamente aos primórdios do século XIX, pois, como recorda José Carlos Vieira de Andrade, o mesmo chegou até o século XXI. ${ }^{15}$

É curioso anotar como a separação de poderes serviu, contraditoriamente, a esse processo de imunização decisória dos órgãos do Poder Executivo. O mesmo princípio que justificara a criação do contencioso administrativo. intestino ao Executivo, será invocado para impedir que os órgãos de controle exerçam sobre os outros órgãos da Administração poderes de injunção e substituição, em princípio legítimos e até naturais entre órgãos situados no interior da mesma estrutura de Poder. Em outras palavras, criou-se no interior da Administração um contencioso que não oferecia ao administrado as mesmas garantias processuais dos tribunais judiciários, mas, estranhamente, estava sujeito aos mesmos limites externos de atuação, como se se tratasse do próprio Poder Judiciário. Se algum sentido garantístico norteou e inspirou o surgimento e desenvolvimento da dogmática administrativista, este foi em favor da Administração, e não dos cidadãos. ${ }^{16}$

Nesse contexto, as categorias básicas do direito administrativo, como a de discricionariedade e sua insindicabilidade perante os órgãos contenciosos, supremacia do interesse público e prerrogativas jurídicas da Administração, são tributárias deste pecado original consistente no estigma da suspeita de parcialidade de um sistema normativo criado pela Administração Pública em proveito próprio, e que ainda se arroga o poder de dirimir em caráter definitivo, e em causa própria, seus litígios com os administrados. ${ }^{17} \mathrm{Na}$ melhor tradição absolutista, além de propria-

14 V. Paulo Otero, ob. cit., p. 276.

15 José Carlos Vieira de Andrade, A Justiça Administrativa (Liçōes), 1999, p. 50-1.

16 Maurice Hauriou, em seu Précis Élémentaire de Droit Administratif, 1943, p. 19, afirma que são as prerrogativas especiais da autoridade administrativa que funcionam como causa $e$ medida da independência científica do direito administrativo. Paulo Otero, a seu turno, na obra Direito Administrativo - Relatório, 2001, p. 227, afirma que só por manifesta ilusão de ótica ou equívoco se poderá vislumbrar uma gênese garantística no direito administrativo - o direito administrativo nasce como direito da Administração Pública e não como direito dos administrados.

17 V., neste sentido, João Baptista Machado, Introdução ao Direito e ao Discurso Legitimador. 1989 , p. 1989. 
mente administrar, os donos do poder criam o direito que lhes é aplicável e o aplicam às situações litigiosas com caráter de definitividade.

Captando tal evidência, Diogo de Figueiredo Moreira Neto afirma, com propriedade, que os conceitos ligados à preservação da autoridade "assomaram a tal importância estruturante que a literatura jurídica do direito administrativo tornou-se praticamente unânime quanto à articulação dogmática da disciplina sobre a idéia central - magistralmente sintetizada por Umberto Allegretti - de que o interesse público é um interesse próprio da pessoa estatal, externo e contraposto aos dos cidadãos". ${ }^{18}$

Vale notar que a relutância dos países vinculados à common law - seja na sua versão original inglesa, seja na sua versão mesclada e híbrida norte-americana em reconhecer autonomia científica ao direito administrativo ${ }^{19} \mathrm{e}$ o repúdio à adoção da jurisdição administrativa deveu-se à tradição existente naquelas nações de submissão das relações entre Administração e cidadãos às mesmas regras e aos mesmos juízes que decidiam os litígios entre particulares. Embora também lá tenham existido — e ainda existam — normas que contemplavam imunidades ao poder político ( $v . g$., a idéia da irresponsabilidade civil do Estado expressa na máxima the king can do no wrong, só superada em meados do século $\mathrm{XX}$ ), o direito administrativo não se formou como uma estrutura dogmática munida de categorias a serviço do poder.

No Brasil, o modelo de administração implantado a reboque da colonização de exploração, somado ao patrimonialismo da coroa portuguesa que se tornou nota característica da cultura política brasileira, encontrou no figurino francês do direito administrativo material farto para se institucionalizar e legitimar. Como se pretende demonstrar ao longo da tese, as peculiaridades da Admnistração Pública brasileira apenas aguçaram a crise de identidade que o modelo jusadministrativista europeu continental já trazia desde a sua gênese.

\section{A crise dos paradigmas do direito administrativo e a emergência de um novo modelo teórico}

Como já acima brevemente antecipado, a crise dos paradigmas do direito administrativo não constitui algo novo, mas é, em verdade, vício de origem. As transformações por que passou o Estado moderno, especialmente a crise do Estado Providência verificada nas últimas décadas do século $\mathrm{XX}$, apenas sublinharam e

18 Diogo de Figueiredo Moreira Neto, Mutações do Direito Administrativo, 2000, p. 10/11.

19 Como se sabe, embora a prática regulatória norte-americana remonte à segunda metade do século XIX, o direito administrativo só vem a ser reconhecido nos Estados Unidos como disciplina autônoma muito tempo depois, já no século $\mathrm{XX}$. A rigor, no entanto, não há naqueles países a adoção das mesmas categorias do direito administrativo de tradição continental, sendo antes a disciplina identificada com o complexo normativo regulador editado por agências reguladores independentes e agências executivas. V., sobre o tema, Breyer, Stewart, Sunstein and Spitzer, Administrative Law and Regulatory Policy - Problems, Text, and Cases, Aspen Law and Business, 2002. 
agravaram o descompasso entre as velhas categorias e as reais necessidades e expectativas das sociedades contemporâneas em relação à Administração Pública.

Nesta toada, é possível identificar três paradigmas clássicos do direito administrativo que fizeram carreira no Brasil e que se encontram em xeque na atualidade:

I) o dito princípio da supremacia do interesse público sobre o interesse privado, que serviria de fundamento e fator de legitimação para todo o conjunto de privilégios de natureza material e processual que constituem o cerne do regime jurídico-administrativo. ${ }^{20}$

II) a legalidade administrativa como vinculação positiva à lei, traduzida numa suposta submissão total do agir administrativo à vontade previamente manifestada pelo Poder Legislativo. Tal paradigma costuma ser sintetizado na negação formal de qualquer vontade autônoma aos órgãos administrativos, que só estariam autorizados a agir de acordo com o que a lei rigidamente prescreve ou faculta. ${ }^{21}$

III) a intangibilidade do mérito administrativo, consistente na incontrolabilidade das escolhas discricionárias da Administração Pública, seja pelos órgãos do contencioso administrativo, seja pelo Poder Judiciário (em países, como o Brasil, que adotam o sistema de jurisdição una), seja pelos cidadãos, através de mecanismos de participação direta na gestão da máquina administrativa. ${ }^{22}$

Como agente condutor básico da superação dogmática de tais categorias jurídicas, erige-se hodiernamente a idéia de constitucionalização do direito administrativo como alternativa ao déficit teórico apontado no capítulo anterior, pela adoção dos sistemas de direitos fundamentais e de democracia, tal como instituídos na Constituição, como vetores axiológicos — traduzidos em parâmetros jurídicos — a pautar a atuação da Administração Pública. Tais vetores convergem no princípio maior da dignidade da pessoa humana e, (I) ao se situarem acima e para além da lei, (II) vincularem juridicamente o conceito de interesse público e (III) estabelecerem balizas principiológicas para o exercício da discricionariedade administrativa, fazem ruir o arcabouço dogmático do velho direito administrativo. ${ }^{23}$

20 Neste sentido, v. Celso Antônio Bandeira de Melo, O Conteúdo do Regime Jurídico-Administrativo e seu Valor Metodológico, Revista de Direito Público, vol. 2, 1967, p. 45-7.

21 Tal formulação clássica é devida, entre nós, a Hely Lopes Meirelles, Direito Administrativo Brasileiro, 1995, p. 82-3: “Na Administração não há liberdade nem vontade pessoal. Enquanto na administração particular é lícito fazer tudo que a lei não proibe, na Administração Pública só é permitido fazer o que a lei autoriza."

22 Maria Sylvia Zanella Di Pietro, Discricionariedade Administrativa na Constituição de 1988, 1991, p. 93 e segs..

23 Neste sentido, Patrícia Ferreira Baptista, Transformações do Direito Administrativo, 2003, p. 129-30: "(...) Da condição de súdito, de mero sujeito subordinado à Administração, o administrado foi elevado à condição de cidadão. Essa nova posição do indivíduo, amparada no desenvolvimento do discurso dos direitos fundamentais, demandou a alteração do papel tradicional da Administração Pública. Direcionada para o respeito à dignidade da pessoa humana, a Administração, constitucionalizada, vê-se compelida a abandonar o modelo autoritário de gestão da coisa pública para se transformar em um centro de captação e ordenação dos múltiplos interesses existentes no substrato social." 
Assim, tem-se que:

(i) a Constituição, e não mais a lei, passa a se situar no cerne da vinculação administrativa à juridicidade;

(ii) a definição do que é o interesse público, e de sua propalada supremacia sobre os interesses particulares, deixa de estar ao inteiro arbítrio do administrador, passando a depender de juízos de ponderação proporcional entre os direitos fundamentais e outros valores e interesses metaindividuais constitucionalmente consagrados;

(iii) a discricionariedade deixa de ser um espaço de livre escolha do administrador para convolar-se em um residuo de legitimidade, ${ }^{24}$ a ser preenchido por procedimentos técnicos e jurídicos prescritos pela Constituição e pela lei com vistas à otimização do grau de legitimidade da decisão adminisiıativa. Por sua importância no contexto democrático e de implementação dos direitos fundamentais, tem-se dado ênfase à participação e à eficiência como mecanismos de legitimação das escolhas discricionárias da Administração Pública.

$\mathrm{Na}$ tarefa de desconstrução dos velhos paradigmas e proposição de novos, a tessitura constitucional assume papel condutor determinante, funcionando como diretriz normativa legitimadora das novas categorias sugeridas. A premissa básica a ser assumida é a de que as feições jurídicas da Administração Pública — e, a fortiori, a disciplina instrumental e finalística da sua atuação - estão alicerçadas na própria estrutura da Constituição, a partir das quais o Estado-Administrador deverá se organizar para proteger, promover e compatibilizar direitos individuais e interesses gerais da coletividade.

O propósito do presente ensaio é o de demonstrar a inconsistência teórica do dito princípio da supremacia do interesse público sobre o particular com uma sistemática constitucional cidadã, comprometida com a proteção e promoção dos direitos individuais de maneira ponderada e compatível com a realização das necessidades e aspirações da coletividade como um todo. Para o alcance de tal desiderato, o direito administrativo não tem mais como ser explicado a partir de um postulado de supremacia, mas de proporcionalidade.

\section{Construção e Desconstrução do Princípio da Supremacia do Interesse Público}

\section{III.1. O princípio da supremacia do interesse público, segundo a doutrina} brasileira

A doutrina e a jurisprudência brasileiras, em sua grande maioria, sustentam a existência de um princípio de supremacia do interesse público sobre o privado,

24 A expressão é devida a Diogo de Figueiredo Moreira Neto, Legitimidade e Discricionariedade - Novas Reflexões sobre os Limites e Controle da Discricionariedade, 2002, p. 33. 
implícito no texto constitucional. ${ }^{25}$ Os juristas em geral enfrentam a temática com grande naturalidade e, de fato, prevalece o panorama de um pensamento pacificado, para o qual a existência do princípio em comento não ensejaria qualquer contestação.

Dentre os mais renomados administrativistas brasileiros, destaca-se, como ferrenho defensor do dito princípio. Celso Antônio Bandeira de Mello, que elabora seu discurso partindo de uma preliminar conceituação de interesse público, estendendose até os efeitos gerados pela aplicação do princípio decorrente de tal conceituação ao direito administrativo pátrio. ${ }^{26}$ Neste sentido, apresenta a noção de interesse público como uma projeção de interesses individuais e privados em um plano coletivo, ou seja. um interesse comum a todos os indivíduos, e que representa o ideal de bem-estar e segurança almejado pelo grupo social. ${ }^{27}$ Assim, na medida em que procura enfatizar a existência de um elemento de ligação entre ambos os interesses (público e privado), rejeita a dissociação completa dos conceitos. Ao adotar uma concepção orgânica da relação entre indivíduo e coletividade, apresentada como inerente aos conceitos de sociedade e de Estado de Direito, conclui o autor com a idéia de que interesse público e interesse coletivo são sinônimos. ${ }^{28}$

Na sequiência, Bandeira de Mello nos direciona a uma análise, ainda que sucinta, do conceito e da aplicação do princípio da supremacia do interesse público sobre o privado, na qual resta estampada com nitidez a sua dificuldade em ser fiel a suas premissas teóricas. ${ }^{29}$ Confira-se:

25 Segundo Fábio Medina Osório, "evidentemente que a superioridade do interesse público sobre o privado não pode ser deduzida de princípios exclusivamente morais ou políticos, pois carece de uma recondução à normatividade própria da CF”. OSÓRIO, Fábio Medina. Existe uma Supremacia do Interesse Público sobre o Privado no Direito Administrativo Brasileiro?. In Revista de Direito Administrativo, v. 220. Rio de Janeiro: Renovar, abr/jun. 2000. p. 84.

26 Celso Antônio Bandeira de Mello, Curso de Direito Administrativo. São Paulo: Malheiros, 2003.

27 Para Celso Antônio Bandeira de Mello: "o interesse público deve ser conceituado como o interesse resultante do conjunto dos interesses que os indivíduos pessoalmente têm quando considerados em sua qualidade de membros da Sociedade, e pelo simples fato de o serem". Celso Antônio Bandeira de Mello, op. cit. p. 53.

28 Na seqüência, somente pincela alguns comentários no sentido de destacar a posição superior dos interesses públicos, polarizando, assim, a discussão em torno das noções de interesse público primário e secundário. Neste ponto, visa, com afinco, distanciar interesses próprios do Estado como pessoa jurídica e o interesse a ele incumbido pela população, o interesse público "original".

Na passagem a seguir, em que discorre sobre esta relação enire as dimensões do público e do privado, Bandeira de Mello deixa clara sua posição sobre a relação de hierarquia entre os interesses em questão: "Uma pista importante para perceber-se que o chamado interesse público - em despeito de seu notável relevo e de sua necessária prevalência sobre os interesses pessoais peculiares de cada um - não é senão uma dimensão dos interesses individuais..." (grifamos). Celso Antonio Bandeira de Mello, op. cit. p.51.

"Assim, independentemente do fato de ser, por definição, encarregado dos interesses públicos, o Estado pode ter tanto quanto as demais pessoas, interesses que lhe são particulares, individuais, e que tal como os interesses delas, concebidas em suas meras individualidades, se encarnam no Estado enquanto pessoa". Op. cit. 57.

29 Op. cit. p. 60. 
"Trata-se de verdadeiro axioma reconhecível no moderno Direito Público. Proclama a superioridade do interesse da coletividade, firmando a prevalência dele sobre o particular, como condição até mesmo, da sobrevivência e asseguramento deste último. É pressuposto de uma ordem social estável, em que todos e cada um possam sentir-se garantidos e resguardados".

O problema teórico nodal, ao qual adiante se retornará, encontra-se na adoção de uma concepção unitária de interesse público, como premissa, e na afirmação, em seguida, de um princípio de supremacia do público (coletivo) sobre o particular (individual). Afinal, que sentido há na norma de prevalência se um interesse não é mais que uma dimensão do outro? Mais que isto: a dita norma de prevalência não esclarece a questão mais importante da dicotomia público/privado ou coletivo/individual: qual a justa medida da prevalência de um sem que haja a ablação total do outro?

É interessante observar que a partir daí e até o fim da sua exposição, o autor se concentra na vinculação entre determinadas prerrogativas da Administração Pública e o princípio da supremacia do interesse público, já que aquelas, a priori, justificarse-iam como consequiência da aplicação deste último. Diante disso, é possível extrair que o eixo da discussão levada a cabo pelo autor não gira em torno exatamente do princípio da supremacia, mas dos efeitos que este gera para a Administração.

Em sintonia com a opinião de Celso Antônio, Maria Sylvia Zanella Di Pietro propõe-se a abordar a temática em pauta, valendo-se da bipolarização público-privado. Assinala a autora que, mesmo diante de uma relativização desse posicionamento, trazida pelos novos tempos, há determinados axiomas não se pode ignorar. Dentre elas, ressalta a função específica das normas de direito público, qual seja, "atender os interesses públicos, o bem estar coletivo" ${ }^{30}$. Neste diapasão, menciona o interesse particular como mero interesse reflexo, quando em análise no contexto de normas de direito público. Essas delimitariam o seu âmbito de incidência a um plano único, no qual não se comportaria atender interesses de cunho individual.

Adiante, ao reiterar a relevância do dito princípio para o exercer das atividades administrativas, lança o seguinte pensamento: "Se a lei dá à Administração os poderes de desapropriar, de requisitar, de intervir, de policiar, de punir, é porque tem em vista atender ao interesse geral, que não pode ceder diante do interesse individual" ${ }^{31}$. Não há como negar, destarte, que todo o seu discurso caminha no sentido de confirmar a existência do princípio em análise, e nele identificar a "sede principal" do Direito Constitucional e Administrativo.

Entretanto, avaliando mais detidamente as idéias da autora, é possível perceber, se focalizadas por outro ângulo, que a noção por si apresentada para interesse público, permeia-se, por vezes, de características peculiares a outros princípios. Ao apontar em seu texto, por exemplo, a contraposição existente entre o interesse público e favorecimentos pessoais ou disputas políticas, Di Pietro acaba por adentrar distinto 
campo argumentativo, o qual se vincula estreitamente com os princípios da impessoalidade e da moralidade. ${ }^{32}$ A gestão da coisa pública pressupõe para o administrador o afastamento de interesses de ordem pessoal, que venham a desvirtuar a atuação do Poder Público. De fato, essa diretriz não passa de uma versão um tanto mais analítica do significado dos princípios da impessoalidade e da moralidade.

Tal é um equívoco comum na doutrina pátria: aponta-se como exemplo de aplicação do princípio da supremacia do interesse público sobre o particular a invalidação de favorecimentos pessoais no uso da máquina administrativa. Ora, os interesses particulares e individuais de que se cuida, na análise do princípio, não são, por evidente, aqueles ilegítimos, assim considerados por força de outras normas constitucionais. A questão da dicotomia público/particular só se coloca quando a Administração Pública se vê diante de interesses legítimos de parte a parte, quando então deverá socorrer-se de algum parâmetro normativo para balancear os interesses em jogo na busca da solução constitucional e legalmente otimizada.

Hely Lopes Meirelles, a seu turno, afirma que o direito privado e o direito público encontrariam na relação entre os seus sujeitos de direito a sua principal distinção, visto que o primeiro basear-se-ia na paridade entre referidos sujeitos, ao passo que o segundo pautaria dita relação no princípio da supremacia do interesse público sobre o privado, ou seja, na supremacia do Poder Público em face do cidadão. Ademais, tal como Celso Antônio, atrela o princípio da supremacia do interesse público a privilégios e prerrogativas que dele resultam. ${ }^{33}$

Não obstante, ao longo de sua argumentação, o jurista pontua observação específica, a qual, ao cabo e ao fim, faz cair por terra todo o encadeamento lógico de seu posicionamento. Aqui, em passagem singela, que por vezes pode até mesmo passar despercebida, repousa exemplo pontual, contudo característico da confusão que permeia o círculo administrativista, no seu conjunto. Em dado momento, afirma o princípio da supremacia do interesse público, ditado como regra de solução de conflitos:

"Sempre que entrarem em conflito o direito do indivíduo e o interesse da comunidade, há de prevalecer este, uma vez que o objetivo primacial da Administração é o bem comum. As leis administrativas visam, geralmente, a assegurar essa supremacia do Poder Público sobre os indivíduos, enquanto necessária à consecução dos fins da Administração" ${ }^{34}$. (grifamos)

32 "Em consequiência. se, ao usar de tais poderes, a autoridade administrativa objetiva prejudicar um inimigo político, ou beneficiar um amigo, conseguir vantagens pessoais para si ou para terceiros, está fazendo prevalecer o interesse individual sobre o privado, e, em consequência, estará se desviando da finalidade pública prevista na lei. Daí o vício do desvio de poder ou desvio de finalidade, que torna o ato ilegal". Idem.

33 "Com efeito, enquanto o Direito Privado repousa sobre a igualdade das partes na relação jurídica, o Direito Público assenta em princípio inverso, qual seja, o da supremacia do Poder Público sobre os cidadãos, dada a prevalência dos interesses coletivos sobre os individuais". Hely Lopes Meirelles, Direito Administrativo Brasileiro. São Paulo: Malheiros, 2001. p. 43.

34 Ibidem. p.43. 
Em instante seguinte, contudo, lança idéia na qual percorre iter inverso:

“Ao aplicador da lei compete interpretá-la de modo a estabelecer equilíbrio entre os privilégios estatais e os direitos individuais, sem perder de vista aquela supremacia". ${ }^{35}$ (grifos nossos)

Nota-se, portanto, a falta de clareza no tocante a qual diretriz filiar-se quando da aplicação do princípio em debate. Parece evidente que o autor não superou o obstáculo da abstração teórica, tornando árdua a tarefa de conectar tais dizeres com a realidade concreta, na qual incide o princípio.

Talvez a mais ampla e completa defesa do princípio da supremacia do interesse público sobre o particular tenha sido empreendida por Fábio Medina Osório. Inicialmente, como pressuposto mesmo à construção de sua tese. Medina Osório admite seja a supremacia do interesse público sobre o privado um princípio constitucional implícito, extraído da leitura sistemática de diversos dispositivos os quais protegem o interesse público na Constituição Federal. Aduz o autor:

"São múltiplas as fontes constitucionais da superioridade do interesse público sobre o privado. Dos princípios constitucionais que regem a Administração Pública decorre a superioridade do interesse público em detrimento do particular, como direção teleológica da atuação administrativa. Resulta clara, na sequiência, a relação entre o imperativo conteúdo finalístico da ação administrativa (consecução do interesse público) e a existência de meios materiais e jurídicos que retratam a supremacia do interesse público sobre o privado, é dizer, as situações de vantagens da Administração em detrimento do particular encontram raízes na existência de fins de utilidade pública perseguíveis pelo Poder Público. De outro lado, a existência de bens coletivos que reclamam proteção estatal e restrições a direitos individuais também retrata um princípio de superioridade do interesse público sobre o particular. Nas normas constitucionais protetivas desses bens e valores coletivos, portanto. está implícita a existência do interesse público e sua superioridade relativamente ao privado" ${ }^{36}$. (grifamos)

"Todos esses dispositivos evidenciam peculiares manifestações do princípio da superioridade do interesse público sobre o privado, dado que do conjunto de muitas dessas regras emerge um elemento comum: a superioridade do interesse público sobre o privado. Há muitas outras normas constitucionais que evidenciam o princípio em exame, na medida em que protegem bens coletivos $^{37}$. (grifamos)

Os trechos destacados, como se vê, deixam transparecer a tese em favor da prevalência do coletivo sobre o privado, lógica a qual traduziria o princípio da

35 Idem. p.43.

36 lbidem. p. 87. nr 13.

37 lbidem. p. $98 . \mathrm{nr} 48$. 
supremacia do público sobre o privado. Neste diapasão, o autor deixa assente a possibilidade de se distinguirem interesses coletivos de interesses individuais. De acordo com o seu raciocínio, embora. em alguns casos, o interesse público venha a se identificar com o privado, não se pode ignorar a distinção existente entre os interesses públicos, equiparados aos interesses coletivos, e os privados, residindo nesta distinção a separação entre a esfera pública e a privada. Tal dissociação permitiria, portanto, a consagração de um princípio pautado na supremacia enquanto resultado de uma equação na qual se consideram dois fatores: o público e o privado.

$\mathrm{Na}$ sequêencia, Medina Osório procura demonstrar a existência do princípio em apreço indicando sua influência no ordenamento jurídico sob três vertentes: (a) como direção finalística da Administração Pública: (b) como fundamento constitucional de normas que outorgam privilégios à Administração; e (c) como fundamento para ações administrativas restritivas de direitos individuais.

Na primeira daquelas manifestações, o autor imprime ao princípio da supremacia do interesse público o título de fundamento justificador da ação administrativa. Afirma que a atividade administrativa não pode nunca se divorciar do fim para o qual foi instituída, qual seja, a persecução do interesse público, não sendo possível guiar-se única e exclusivamente sob o influxo de interesses privatísticos. Com tal discurso, o princípio é tido como garantia aos particulares, no sentido de que o Estado não se desviará de sua precípua função de realizar interesses coletivos.

Vale aqui a mesma crítica já feita ao pensamento de Maria Sylvia Di Pietro: a direção finalística dada pela Constituição e pelas leis à Administração Pública necessariamente apartada de quaisquer privilégios ou favorecimentos odiosos a particulares - nada demonstra em relação à dicotomia público/privado. Isto se resolve pelos princípios da impessoalidade e da moralidade, enquanto a direção finalística é dada pela Constituição, em primeiro plano, e pelas leis, logo a seguir.

No que concerne à fundamentação de leis as quais outorgam privilégios à Administração Pública, a argumentação do jurista, com as devidas vênias, revela-se falha. A esse respeito, verifica-se que Medina Osório afirma a possibilidade de controle quanto à outorga de privilégios à Administração Pública, mostrando-se imperiosa uma análise da proporcionalidade e da razoabilidade de tais leis, sob pena de, descumpridos tais postulados, serem as leis declaradas inconstitucionais ${ }^{38}$. Ora. tal possibilidade faz desabar a assertiva de que as outorgas de privilégios estariam baseadas no princípio da supremacia de interesse público sobre o privado. Isso porque, se existente o referido princípio, não seria possível taxar de inconstitucional uma lei que privilegiasse os interesse coletivos e estatais (interesse público), em detrimento de interesses privados. Tal princípio, absoluto, posto que prega a prevalência de um interesse sobre o outro, legitimaria toda e qualquer outorga de vantagens à Administração, prescindindo de qualquer análise a respeito de sua razoabilidade e proporcionalidade. Em síntese: a idéia de supremacia como norma jurídica não se

38 "Nesse passo, a máxima da proporcionalidade é perfeitamente compatível como princípio do interesse público, visto que este não pode incidir desprovido de racionalidade, carente de ponderação ou do processo ínsito à incidência de todo e qualquer princípio constitucional". Ibidem. p. 106. 
coaduna com os postulados da proporcionalidade e da razoabilidade, que preconizam a cedência recíproca entre interesses em conflito.

Por fim, o autor aponta uma última manifestação do princípio em debate: a sua função justificadora de restrições aos direitos individuais. Confira-se o que afirma a este propósito:

"A ordem jurídica infraconstitucional, vinculada aos ditames da $\mathrm{CF}$, especialmente através do Direito Público, consagra ou reflete, em inúmeras ocasiões, o princípio da superioridade do interesse público sobre o privado como justificativa para importantes restrições aos direitos individuais" ${ }^{39}$.

O ponto mais evidente aqui passível de crítica é o de uma circularidade no raciocínio. Com efeito, na Constituição são encontrados os fundamentos para a restrição de direitos individuais em prol de interesses da coletividade. Ora, se é a Constituição que, explícita ou implicitamente, estabelece quando e em que medida direitos individuais podem ser restringidos, (I) o fundamento da restrição é a norma constitucional específica, e não o dito princípio e (II) a medida da restrição, conforme permitida pela Constituição, é dada por uma norma de proporção e preservação recíproca dos interesses em conflito, e não de prevalência a priori do coletivo sobre $\mathrm{o}$ individual.

\section{III.2. A desconstrução do princípio da supremacia do interesse público}

Desde o trabalho pioneiro de Humberto Bergmann Ávila ${ }^{40}$, em que se demonstrou de forma cabal o vazio conceitual do dito princípio da supremacia do interesse público sobre o interesse privado, que o tema está a carecer de um tratamento sistemático. Segundo Ávila, o referido "princípio" não pode ser entendido como norma-princípio, seja sob o prisma conceitual, seja sob o normativo, nem tampouco pode ser compreendido como um postulado normativo.

Conceitualmente, é possível, de plano, apartar o "princípio" em tela de toda construção doutrinária acerca dos princípios jurídicos. Neste ponto, fica claro o divórcio entre a regra abstrata de prevalência absoluta em favor do interesse público e a aplicação gradual dos princípios proporcionada pelo caráter abstrato dos mes$\operatorname{mos}^{41}$. Ou seja, o referido princípio, porquanto determine a preferência absoluta ao

39 Ibidem. p. 99.

40 Humberto Bergmann Ávila, Repensando o "Princípio da supremacia do interesse público sobre o particular", in O Direito Público em Tempos de Crise - Estudos em Homenagem a Ruy Ruben Ruschel, 1999, p. 99-127.

41 O autor que ora se analisa. em obra-prima sobre os princípios, leciona de forma irretocável: "No caso dos princípios o grau de abstração é maior relativamente à norma de comportamento. já que eles nāo se vinculam abstratamente a uma situação específica (por exemplo, princípio democrático, Estado de Direito); no caso das regras, as conseqüências são de pronto verificáveis, 
interesse público diante de um caso de colisão com qualquer que seja o interesse privado, independentemente das variações presentes no caso concreto, termina por suprimir os espaços para ponderações.

$\mathrm{Na}$ esteira da incompatibilidade conceitual, cumpre ressaltar que "o princípio da supremacia do interesse público" também não encontra respaldo normativo, por três razões tratadas pelo autor: a uma, por não decorrer da análise sistemática do ordenamento jurídico; ${ }^{42}$ a duas, por não admitir a dissociação do interesse privado, colocando-se em xeque o conflito pressuposto pelo "princípio"; e a três, por demonstrar-se incompatível com os postulados normativos erigidos pela ordem constitucional.

Partindo da sistemática constitucional vigente, conclui o autor com facilidade pela ausência de fundamento de validade do indigitado "princípio". Isso porque a organização da Constituição brasileira volta-se precipuamente para a proteção dos interesses do indivíduo. Advinda dos argutos anseios pelo retorno à ordem democrática, outrora corrompida pela hipertrofia do Poder Executivo nos governos militares, a Carta de 1988 é farta de normas e princípios ilustrativos do espírito cidadão da atual Constituição brasileira (v.g., preâmbulo, artigos $1^{\circ}, 3^{\circ}$ a $17,145,150,170$, 196, 201, 203, 205, 206, 220, 226, 227).

Vale dizer: a Lei Maior é orientada sob o influxo do princípio da dignidade da pessoa humana ${ }^{43}$, do que deflui a necessidade de se estabelecer, em alguma medida, proteção ao interesse do indivíduo quando ameaçado frente aos interesses gerais promovidos pelo Estado.

Dessa forma, verifica-se não ser possível extrair "o princípio da supremacia do interesse público" da análise do conjunto normativo constitucional, haja vista a ampla proteção dispensada aos interesses particulares, de tal maneira que aceitá-lo como norma-princípio é deixar subsistir a contrariedade sistêmica que representa e afrontar a constante busca pela unidade constitucional.

O conteúdo constitucional descrito presta-se também como fundamento a negar a colisão entre interesses públicos e privados, pressuposta pelo "princípio" em debate. Verifica-se que ambos encontram-se enraizados na Lei Maior, de sorte a haver uma "conexão estrutural" entre eles e não essa efetiva contradição. Nas palavras de Ávila, "O interesse privado e o interesse público estão de tal forma instituídos pela Constituição brasileira que não podem ser separadamente descritos

ainda que devam ser corroboradas por meio do ato de aplicação". ÁVILA, Humberto Bergmann. Teoria dos Princípios — da definição à aplicação dos princípios jurídicos. p.40.

42 Assim define Humberto Bergmann Ávila, como "ausência de fundamento de validade". ÁVILA, Humberto Bergmann, op. cit.

43 "A opção da Constituição de 1988 pela dignidade da pessoa humana é robustecida ainda pelo exame sistemático da própria Carta (...). É que o constituinte, além de fixar a dignidade como principio central do Estado, juridicizando o valor humanista, disciplinou a matéria ao longo do texto através de um conjunto de outros princípios, subprincípios e regras, que procuram concretiza-lo e explicitar os efeitos que dele devem ser extraidos". BARCELLOS, Ana Paula de. A Eficácia Jurídica dos Principios Constitucionais: O Princípio da Dignidade da Pessoa Humana. Rio de Janeiro: Renovar, 2002. p. 28. 
na análise da atividade estatal e de seus fins. Elementos privados estão incluídos nos próprios fins do Estado (p. ex. preâmbulo e direitos fundamentais)" ${ }^{44}$

A abordagem acanhada do autor a respeito do que vai chamar de "indissociabilidade do interesse privado" merece, pela relevância, maiores reflexões. Não apenas cuida-se tal indissociabilidade da existência de um ordenamento pautado por garantias e direitos individuais ao qual deve submeter-se o Estado; a assertiva vai além, traduzindo a idéia de que a realização de interesses particulares quando em confronto com interesses públicos não constitui desvio de finalidade para a Administração, pois aqueles são também fins públicos, conforme restará demonstrado mais à frente.

O que se verifica é que a proteção de um interesse privado constitucionalmente consagrado, ainda que parcialmente, pode representar, da mesma forma, a realização de um interesse público. Ao cabo deste trabalho, ficará demonstrado que, ao contrário do que se acredita, a satisfação de um representa igualmente o sucesso do outro.

Por fim, cumpre traçar o derradeiro argumento manejado pelo autor para concluir pela descaracterização do princípio da supremacia do interesse público como norma-princípio, qual seja, a sua incompatibilidade com os postulados normativos da proporcionalidade e da concordância prática ${ }^{45}$, que andam atrelados na busca de uma exata medida da realização máxima de bens jurídicos contrapostos.

$O$ postulado da proporcionalidade. remansosamente reconhecido pela doutrina e jurisprudência como princípio, é condição para o conhecimento de normas jurídicas. Tal postulado orienta a interpretação e aplicação de normas no sentido de acomodar os bens jurídicos em jogo, sem que se exclua um em prol da subsistência do outro. Ou seja, dentre as opções disponíveis, todas são otimizadas em algum nível. Este é o dever de ponderação ${ }^{46}$, ao qual se liga o postulado da proporcionalidade.

Com efeito, nota-se que não há como conciliar no ordenamento jurídico um "princípio" que, ignorando as nuances do caso concreto, pré-estabeleça que a melhor solução consubstancia-se na vitória do interesse público. O "princípio" em si afasta o processo de ponderação, fechando as portas para os interesses privados que estejam envolvidos. Dê-se destaque, outrossim, ao fato da fórmula pré-concebida presente no "princípio" ir de encontro ao dever de fundamentação ("dever de explicitação das premissas" ${ }^{47}$ ) a que se sujeitam os Poderes do Estado.

Fato é que o "princípio" em questão, ao rejeitar as especificidades de cada caso, impondo uma única e invariável relação de prevalência do interesse público, termina

44 Humberto Bergmann Ávila, op. cit. p.111.

$45 \mathrm{O}$ autor em questão cuida de defini-los: "Postulados, no sentido Kantiano, significa uma condição de possibilidade do conhecimento de determinado objeto, de tal sorte que ele não pode ser apreendido sem que essas condições sejam preenchidas no próprio processo de conhecimento. (...) Os postulados normativos são entendidos como condições de possibilidade do conhecimento do fenômeno jurídico". Op. cit., p.103.

46 Veja-se, em importante obra sobre o tema: Daniel Antonio de Moraes Sarmento, A ponderação de Interesses na Constituiçāo Federal. Rio de Janeiro: Lumen Juris, 2002.

47 Humberto Bergmann Ávila, op. cit. p.115. 
por distanciar-se do princípio da proporcionalidade, mormente no que tange às suas acepções - adequação (o meio escolhido deve ser apto a atingir o fim a que se destina), necessidade (dentre os meios hábeis, a opção deve incidir sobre o menos gravoso em relação aos bens envolvidos) e proporcionalidade em sentido estrito (a escolha deve trazer maiores benefícios do que a restrição proporcionada) —, nas quais sobressalta a relevância da análise casuística pelo aplicador e intérprete da norma. ${ }^{48}$

Similar ao postulado da proporcionalidade, a concordância prática viabiliza o exercício da ponderação ao afirmar a coordenação entre os bens jurídicos e negar-lhes uma posição antípoda, quando se apresentam, ambos, constitucionalmente protegidos.

Fica evidente, assim, o esvaziamento do referido princípio como fundamento de validade para qualquer intervenção estatal, que, pelo princípio da legalidade, pressupõe previsão normativa. Nesse sentido, assevera com precisão o jurista gaúcho:

"Em vez de um princípio de preferência deve ser atribuída a importância, então, às prescrições constitucionais e legais, já que elas - e não, portanto, o citado 'princípio' - é que são juridicamente decisivas. (...) Uma norma de preferência só pode ser uma norma individual e concreta, algo bem diverso de uma tendência abstrata". ${ }^{49}$

Passando à segunda etapa de seu trabalho, Ávila propõe-se a analisar a possibilidade de o "princípio da supremacia do interesse público sobre o privado" funcionar como um postulado normativo, ou seja, como elemento explicativo do fenômeno jurídico.

Tal como na empreitada anterior - atinente à categoria das normas-princípio - o jurista reúne argumentos suficientes a fundamentar uma resposta negativa. Sucintamente, são eles:

a) Face a diversidade de interesses consagrados constitucionalmente, os quais se impõem à consideração do intérprete/aplicador do Direito, um princípio explicativo do Direito Administrativo não pode apresentar-se como uma regra de preferência. Pelo contrário. Fosse o caso de se estabelecer um postulado, tal seria, nas palavras do autor, um "postulado da unidade da reciprocidade de interesses" ${ }^{50}$, o qual, voltado para o bem comum, determinasse, como condição para compreensão do fenômeno jurídico, a consideração recíproca dos diversos valores em jogo;

b) ademais, a enunciação da prevalência indiscriminada do interesse público sobre o particular enquanto condição imprescindível à explicação do ordenamento jurídico depende da verificação de determinados pressupostos, os quais não se observam no caso do "princípio" em comento. São eles:

48 Por todos: Suzana de Toledo Barros. O Principio da Proporcionalidade e o Controle de Constitucionalidade das Leis Restritivas de Direitos Fundamentais.

49 Humberto Bergmann Ávila, op. cit. pp.116/117 e 119.

so lbidem. pp. $119 / 121 / 126$ e 127. 
b.1) a dissociabilidade entre interesses públicos e privados, indispensável para se afirmar a predominância de um sobre o outro. Não obstante, considerando que $o$ bem comum inclui o bem de suas partes, realizar o interesse público passa, necessariamente, pela consideração dos cidadãos em sua dimensão individual. Público e privado colocam-se, assim, em posição de irresistível vinculação, o que contraria o pressuposto dantes arrolado;

b.2) a relação bipolar Estado/cidadão, enquanto objeto central do direito administrativo, apresenta-se em tom necessário e inexorável. Na prática, contudo, constata-se o caráter cada vez mais multipolar das relações ditas administrativas, permeadas que são por vínculos nos quais inexiste necessária contraposição entre o público e o privado;

b.3) por fim, eventual reconhecimento da supremacia do interesse público enquanto postulado normativo do Direito Administrativo depende da possibilidade de determinação objetiva e abstrata do conceito de "interesse público". Um tal requisito, contudo, não pode ser atendido. Somente a partir da concretização das normas constitucionais e legais vigentes (essas, sim, juridicamente relevantes) podese alcançar, em determinada circunstância, a dimensão do que seja o interesse público.

Por razões, portanto, de ordem normativa e lógica, conclui o autor que o conhecimento do direito não se submete a uma condição que mande prevalecer, aprioristicamente, o interesse público em detrimento do privado.

Assim é que, valendo-se dos argumentos acima expendidos, Ávila refuta a existência de um princípio (quer norma-princípio, quer postulado normativo) de "supremacia do interesse público sobre o privado" a guiar o direito administrativo brasileiro.

Em vez de uma regra de prevalência, impõe-se ao intérprete/aplicador do Direito um percurso ponderativo que, considerando a pluralidade de interesses jurídicos em jogo, proporcione solução capaz de realizá-los ao máximo. E "é essa ponderação para atribuir máxima realização aos direitos envolvidos o critério decisivo para a atuação administrativa". ${ }^{51}$

IV. A Constitucionalização do Direito Administrativo e a Formulação de um Novo Paradigma da Administração Pública

\section{IV.1. O dever de proporcionalidade como fundamento e técnica da decisão administrativa}

O constitucionalismo moderno surge quando da superação dos regimes absolutistas, advindo da necessidade de contenção do poder do Estado. Tal escopo instrumentalizou-se a partir da proteção de um conjunto de direitos que, positivados em uma Constituição, foram erigidos a um nível hierárquico superior. Historicamente, 
podem-se verificar precedentes daquele que, mais tarde - fins do século XVIII e início do XIX - viria a ser reconhecido como o fenômeno do constitucionalismo. A história dá notícia de que, em épocas remotas, existiram documentos que, fazendo as vezes de Constituições, protegiam direitos vários, a exemplificar a Magna Carta, datada de 1215 .

A grande inovação das Constituições da modernidade consiste em que, permeadas pelos ideais humanistas, posicionam o homem no epicentro do ordenamento jurídico, verdadeiro fim em si mesmo, a partir do qual se irradia um farto elenco de direitos fundamentais. Tais direitos têm assento, sobretudo, nas idéias de dignidade da pessoa humana e de Estado Democrático de Direito, servindo, concomitantemente, à legitimação e à limitação do poder estatal.

Em que pese o destaque que ostentam os direitos fundamentais no regime democrático-constitucional, fato é que, como condição mesma à vida em sociedade e à própria proteção e promoção dos aludidos direitos, faz-se necessário, também, tutelar interesses de cunho nitidamente coletivo, voltados a atender demandas que ultrapassam a esfera individual dos cidadãos. É essa a justificativa para o constituinte, em um número significativo de casos, ter reconhecido direitos de natureza transindividual e permitir a limitação de interesses individuais em prol da tutela de anseios difusos. Citem-se, nesse sentido, o direito do meio ambiente e a função social da propriedade; o instituto da desapropriação e a cobrança de tributos, todos avessos a aspirações puramente particulares.

Depreende-se, assim, que as dimensões individual e coletiva convivem, lado a lado, no texto constitucional, impondo-se como paradigmas normativos a vincular a atuação do intérprete da Constituição. A despeito da dificuldade em torno da caracterização do que seja interesse público, conceito jurídico indeterminado por excelência, pode-se afirmar que a expressão aponta, em sentido lato, para os fundamentos, fins e limites ${ }^{52}$ a que se subordinam os atos e medidas do Poder Público.

Nesse contexto, os valores encampados constitucionalmente, tidos como paradigmas da ordem jurídica, representam interesses públicos, ou seja, diretrizes efetivamente vinculantes para a máquina estatal. Ato contínuo, partindo da premissa de que interesses privados e coletivos coexistem como objeto de tutela constitucional, conclui-se que a expressão interesse público consiste em uma referência de natureza genérica, a qual abarca a ambos, interesses privados e coletivos, enquanto juridicamente qualificados como metas ou diretrizes da Administração Pública. Conseguintemente, o interesse público, num caso específico, pode residir na implementação de um interesse coletivo, mas também na de um interesse eminentemente individual. Este é o caso, v. g., da manipulação do aparato policial em defesa de um cidadão, situação que prestigia o valor segurança individual.

O reconhecimento da centralidade do sistema de direitos fundamentais instituído pela Constituição e a estrutura maleável dos princípios constitucionais inviabiliza a determinação a priori de uma regra de supremacia absoluta do coletivo sobre o

52 Marie-Pauline Deswarte, Intérêt général, bien commun. Revue du droit public. Paris, set-out. 1988. p.1309. 
individual. A fluidez conceitual inerente à noção de interesse público ${ }^{53}$ aliada à natural dificuldade em sopesar quando o atendimento do interesse público reside na própria preservação dos direitos fundamentais, e não na sua limitação em prol de algum interesse contraposto da coletividade, impõem ao legislador à Administração Pública o dever jurídico de ponderar os interesses em jogo, buscando a sua concretização até um grau máximo de otimização. ${ }^{54}$

Note-se bem: não se nega a existência de um conceito de interesse público, como conjunto de "interesses gerais que a sociedade comete ao Estado para que ele os satisfaça, através de ação política juridicamente embasada (a dicção do Direito) e através de ação jurídica politicamente fundada (a execução administrativa ou judiciária do Direito)." 55 O que se está a afirmar é que o interesse público comporta, desde a sua configuração constitucional. uma imbricação entre interesses difusos da coletividade e interesses individuais e particulares, não se podendo estabelecer a prevalência teórica e antecipada de uns sobre outros. Com efeito, a aferição do interesse prevalecente em um dado confronto de interesses é procedimento que reconduz o administrador público à interpretação do sistema de ponderaçōes estabelecido na Constituição e na lei, e. via de regra, o obriga a realizar seu próprio juízo ponderativo, guiado pelo dever de proporcionalidade.

Assim. sempre que a própria Constituição ou a lei (desde que agindo constitucionalmente) não houver esgotado os juízos possíveis de ponderação entre interesses públicos e privados, caberá à Administração lançar mão da ponderação de todos os interesses e atores envolvidos na questão, buscando a sua máxima realização. ${ }^{56} \mathrm{De}$ modo análogo às Cortes Constitucionais, a Administração Pública deve buscar utilizar-se da ponderação para superar as regras de preferência estáticas atuando situativa e estrategicamente com vistas à formulação de certos standards de decisão. Tais standards permitem a flexibilização das decisões administrativas de acordo com as peculiaridades do caso concreto, mas evitam o mal reverso, que é a incerteza jurídica total provocada por juízos de ponderação discricionários produzidos caso a caso.

Veja-se que tal raciocínio ponderativo funciona como verdadeiro requisito de legitimidade dos atos da Administração Pública, traduzindo postura mais objetivamente comprometida com a realização dos princípios, valores e aspirações sociais expressos no documento constitucional. Considerando que, na lógica da separação de poderes, compete precipuamente à Administração Pública implementar projetos

53 Como afirma Eros Roberto Grau em O Direito Posto e o Direito Pressuposto, 2000, p. 25, a questão da definição do interesse público prossegue como a grande questão do direito administrativo.

54 Esta também parecer ser a posição de Paulo Ricardo Schier, Ensaio sobre a Supremacia do Interesse Pliblico sobre o Privado e o Regime Juridico dos Direitos Fundamentais, site www.mundojuridico.adv.br, acessado em 10.04.2003.

55 Diogo de Figueiredo Moreira Neto, Legitimidade e Discricionariedade - Novas Reflexões sobre os Limites e o Controle da Discricionariedade, 2002, p. 13.

56 Assim, Odete Medauar, O Direito Administrativo em Evolução, 1992, p. 183 e Direito Administrativo Moderno, 1998, p. 141. Também Humberto Bergmann Ávila, ob. cit., p. 123. 
legislativos e políticas públicas, fazem parte da rotina do administrador público situações diversas as quais lhe demandam a tomada de decisões investidas, não raro, de larga margem de discricionariedade.

Nessas situações, conforme esposado, não é livre o agente público para decidir por um ou outro caminho. Chamado a realizar um interesse de índole difusa, para cuja implementação se depare, frontalmente. com um interesse particular juridicamente protegido, deve o administrador, à luz das circunstâncias peculiares ao caso concreto, bem como dos valores constitucionais concorrentes, alcançar solução ótima que realize ao máximo cada um dos interesses públicos em jogo. Como resultado de um tal raciocínio de ponderação, tem-se aquilo que convencionamos chamar de melhor interesse público, ou seja, o fim legítimo que orienta a atuação da Administração Pública.

A técnica da ponderação encontra aplicação recente tanto nos países da common $l a w^{57}$, como do sistema continental europeu ${ }^{58}$, como forma de controle da discricionariedade administrativa e de racionalização dos processos de definição do interesse público prevalente. Nesse processo, os juizos de ponderação deverão ser guiados pelo princípio da proporcionalidade.

Como ensina Daniel Sarmento, tratando do tema da ponderação aplicado ao direito constitucional. o princípio (ou postulado, como prefere Humberto Ávila) da proporcionalidade é o instrumento da ponderação. No seu tríplice aspecto - adequação, necessidade e proporcionalidade em sentido estrito - a proporcionalidade guiará o itinerário lógico a ser percorrido pelo administrador com vistas à máxima realização dos interesses em jogo e a causação do menor sacrifício possível de cada um deles. Assim, na ponderação, a restrição imposta a cada interesse em jogo, num caso de conflito entre princípios constitucionais, só se justificará na medida em que: (a) mostrar-se apta a garantir a sobrevivência do interesse contraposto, (b) não houver solução menos gravosa, e (c) o benefício logrado com a restrição a um interesse compensar o grau de sacrifício imposto ao interesse antagônico. ${ }^{59}$

O Supremo Tribunal Federal já teve ocasião de, em diversas oportunidades, aplicar a técnica da ponderação, instrumentalizada através do postulado da proporcionalidade. Confira-se significativo trecho de decisão da lavra do Ministro Gilmar Mendes, que guiou o Plenário da Corte Suprema no julgamento da Intervenção Federal 2.257-6/São Paulo:

“(...) o princípio da proporcionalidade representam um método geral para a solução de conflitos entre princípios, isto é, um conflito entre normas que, ao contrário do conflito entre regras, é resolvido não pela revogação ou redução teleológica de uma das normas conflitantes nem pela explicitação

57 V. Paul Craig, Administrative Law, 1999, p. 644.

58 V. André de Laubadère. Le Controle Jurisdicionnel du Pouvoir Discretionnaire dans la Jurisprudence Recente du Conseil d'État Français, in Mélanges Offerts à Marcel Waline: Le Juge et le Droit Public (obra coletiva), 1974, p. 546-7.

59 Daniel Sarmento, A Ponderação de Interesses na Constituição Federal, 2000, p. 96. 
de distinto campo de aplicação entre as normas, mas antes e tão somente pela ponderação do peso relativo de cada uma das normas em tese aplicáveis e aptas a fundamentar decisões em sentidos opostos. Nessa última hipótese, aplica-se o princípio da proporcionalidade para estabelecer ponderações entre distintos bens constitucionais.

Em síntese, a aplicação do princípio da proporcionalidade se dá quando verificada restrição a determinado direito fundamental ou um conflito entre distintos princípios constitucionais de modo a exigir que se estabeleça o peso relativo de cada um dos direitos por meio da aplicação das máximas que integram o mencionado princípio da proporcionalidade. São três as máximas parciais do princípio da proporcionalidade: a adequação, a necessidade e a proporcionalidade em sentido estrito. Tal como já sustentei em estudo sobre a proporcionalidade na jurisprudência do Supremo Tribunal Federal (...), há de perquirir-se, na aplicação do princípio da proporcionalidade, se em face do conflito entre dois bens constitucionais contrapostos, o ato impugnado afigura-se adequado (isto é, apto para produzir o resultado desejado), necessário (isto é, insubstituível por outro meio menos gravoso e igualmente eficaz) e proporcional em sentido estrito (ou seja, se estabelece uma relação ponderada entre o grau de restrição de um princípio e o grau de realização do princípio contraposto)."

Ademais, para pleno conhecimento dos interesses em jogo e das razões contrapostas, releva de importância na formulação dos juízos de ponderação a participação do cidadão, seja a título de defesa de direitos individuais (participação uti singulus), seja como membro da coletividade, na defesa de interesses difusos e coletivos (participação uti cives). Ao direito do cidadão de sustentar seus próprios interesses, soma-se, com especial importância, o interesse da coletividade na obtenção de juízos de ponderação, e de consequientes decisões administrativas, dotados do conhecimento pleno das circunstâncias fáticas e argumentos jurídicos que envolvem o caso. A participação dos administrados é também, portanto, insumo essencial para alcance do ponto máximo de otimização e racionalidade na produção das decisões.

Neste passo, chega-se à última parte do presente estudo, consistente na demonstração de como o postulado da proporcionalidade se presta a explicar e justificar a lógica estrutural do direito administrativo.

\section{IV.2. A Proporcionalidade e as Normas Instituidoras de Privilégios para a Administração}

As prerrogativas processuais e materiais da Administração Pública, em sua relação com os cidadãos, constituíram, desde os primórdios da disciplina, a matéria-prima básica da qual se nutriu e sobre a qual se erigiu arcabouço teórico do direito administrativo. Todas, sem exceção, justificadas por remissão ao dito princípio da supremacia do interesse público sobre o particular.

Com efeito, no plano processual, prerrogativas como a quadriplicação do prazo para responder e a duplicação dos prazos recursais, a representação legal, sem a 
necessidade de apresentação de procuração, a não produção dos efeitos da revelia, o duplo grau obrigatório de jurisdição, a impenhorabilidade de bens e o sistema de execução mediante precatórios sempre foram justificados como uma projeção natural - aceita quase, ousaria dizer, como um dado da natureza mesma das coisas - da superioridade jurídica dos interesses do Estado em relação aos interesses dos indivíduos, quando postos em juízo.

O Estado, corporificando e personificando o próprio interesse público, faria jus a um conjunto de privilégios processuais. sem os quais os interesses gerais da coletividade poderiam ser comprometidos. O patrimônio estatal e os interesses cometidos à tutela do Poder Público, gozando de uma posição de prevalência sobre o patrimônio e os interesses individuais particulares, deveriam ficar protegidos por normas instituidoras de um tratamento diferenciado e garantístico.

Raciocínio semelhante se desenvolveu a respeito das prerrogativas administrativas de cunho material. As chamadas cláusulas exorbitantes, v.g., elevadas à condição de elementos identificadores dos contratos administrativos, sempre foram justificadas com fulcro na verticalidade das relações travadas entre Estado e particular, em oposição à horizontalidade das relações estabelecidas entre partes privadas. O dito princípio da supremacia do interesse público era invocado para dar supedâneo, por exemplo, à inoponibilidade, pelo particular, da exceção do contrato não cumprido, aos poderes de alteração e extinção unilateral do contrato pelo Poder Público, aos poderes de fiscalizar as atividades do contratado, intervir na sua gestão e aplicar-lhe sanções, dentre outros.

Ocorre que todas as aludidas prerrogativas da Administração, vistas como desequiparações entre o Poder Público e os particulares, não podem ser justificadas à luz de uma regra de prevalência apriorística e absoluta dos interesses da coletividade sobre os interesses individuais. Veja-se, a seguir, por quê.

Em primeiro lugar, porque, como já assentado, a preservação, na maior medida possível, dos direitos individuais constitui porção do próprio interesse público. São metas gerais da sociedade política, juridicamente estabelecidas, tanto viabilizar o funcionamento da Administração Pública, mediante instituição de prerrogativas materiais e processuais, como preservar e promover, da forma mais extensa quanto possível, os direitos dos particulares. Assim, esse esforço de harmonização não se coaduna com qualquer regra absoluta de prevalência a priori dos papéis institucionais do Estado sobre os interesses individuais privados.

Em segundo lugar, é de se sublinhar que a isonomia, tal como os fins de interesse coletivo cometidos aos Poder Público, também está prevista como norma constitucional. Deste modo, as hipóteses de tratamento diferenciado conferido ao Poder Público em relação aos particulares devem obedecer aos rígidos critérios estabelecidos pela lógica do princípio constitucional da igualdade. É dizer: qualquer diferenciação deve ser instituída por lei, além de sujeitar-se, no seu contexto específico e na sua extensão, ao teste da proporcionalidade.

Portanto, para que um privilégio instituído em favor da Administração Pública seja constitucionalmente legítimo, é mister que: 
(I) a compressão do princípio da isonomia, isto é. a discriminação criada em desfavor dos particulares seja apta a viabilizar o cumprimento pelo Estado dos fins que lhe foram cometidos pela Constituição ou pela lei;

(II) o grau ou medida da compressão da isonomia, isto é, a extensão da discriminação criada em desfavor dos particulares deve observar o limite do estritamente necessário e exigível para viabilizar o cumprimento pelo Estado dos fins que the foram cometidos pela Constituição ou pela lei;

(III) por fim, o grau ou medida do sacrifício imposto à isonomia deve ser compensado pela importância da utilidade gerada, numa análise prognóstica de custos para os particulares e benefícios para a coletividade como um todo.

Hipótese ilustrativa da proposta acima alvitrada foi apreciada pelo Supremo Tribunal Federal no julgamento da ADIN n ${ }^{\circ} 1.753-2 / D F$, na qual se discutia a constitucionalidade da ampliação do prazo para a propositura de ações rescisórias pelo Poder Público, de dois para cinco anos.

O relator do feito, Ministro Sepúlveda Pertence, após anotar que a jurisprudência tem transigido com alguns favores legais da tradição do nosso processo civil, como o duplo grau obrigatório e a dilatação dos prazos de resposta e recurso (RE 181130, Min. Celso de Mello, DJ 12.05.1995; RE 196.430. Min. Sepúlveda Pertence, DJ 21.11.1997), deixou consignado que tais discriminações só são toleráveis na medida em que não forem arbitrárias e servirem, $v \cdot g$. , para compensar deficiências da defesa em juízo das entidades estatais. Assim, por exemplo, considerações ligadas à morosidade inerente a um Estado agigantado para que os advogados públicos obtenham as informações e provas de que necessitam para a elaboração de sua defesa ou mesmo a insuficiência crônica de procuradores nos quadros do Poder Público podem ser levadas em conta na formulação do juízo de constitucionalidade das prerrogativas processuais.

Na seqüência, o Ministro Pertence afirma textualmente que as desequiparações que desafiarem a medida da razoabilidade ou da proporcionalidade caracterizam privilégios inconstitucionais. Foi citado, a título ilustrativo, o caso do art. $6^{\circ}$ da MP $314 / 93$ que. no curso da implantação da Advocacia Geral da União, suspendeu todos os prazos da União. No julgamento, o Supremo Tribunal Federal restringiu o alcance da norma, a fim de excluir a sua incidência nos processos em que a defesa da União coubesse à Procuradoria-Geral da Fazenda Nacional, instituição de há muito organizada, em relação à qual, portanto, não corriam os motivos conjunturais que emprestavam razoabilidade ao dispositivo nas causas em que passaria a atuar a nascente Advocacia Geral da União (QO no RE 148754, Min. Carlos Velloso, RTJ 150/888, 891). Em outras palavras, a norma em questão não passou no teste da adequação, de vez que o favor legal não se mostrava apto a servir a qualquer fim público juridicamente relevante.

No julgamento da dilatação do prazo de dois para cinco anos para a propositura de ações rescisórias pelo Poder Público, a posição da Corte também foi guiada pelo dever de proporcionalidade. Numa primeira etapa, o Ministro Pertence buscou demonstrar o que seria, na linha do raciocínio aqui proposto, a inadequação da medida para viabilizar a defesa do Poder Público em relação a sentenças transitadas em julgado passíveis de rescisão. $\mathrm{O}$ argumento utilizado foi o da suficiência do prazo 
existente - dois anos - para permitir o conhecimento do vício e o ajuizamento da competente ação rescisória.

Em uma segunda etapa do aresto, o relator buscou caracterizar o que aqui seria identificado como desnecessidade ou inexigibilidade da medida. Com efeito, a medida compressiva da isonomia ia além do necessário na medida em que, fosse a ampliação do prazo realmente conveniente, deveria a mesma beneficiar ambas as partes, e não apenas o Poder Público. A restrição à isonomia processual não constituía meio necessário para melhor viabilizar a defesa do Estado em juízo.

Além disso, levou em conta a Corte, na formação de sua convicção. o fato de a medida ir somar-se a vários outros favores legais de natureza processual já conferidos à Fazenda Pública. Como averbou o Ministro Pertence. tais privilégios já produzem conseqüência suficientemente gravosa aos particulares, retardando longamente a satisfação de direito seu reconhecido em juízo. Destarte, a instituição de mais um privilégio - qual seja, o prazo de cinco anos para a propositura da ação rescisória pela Fazenda - geraria situação de desequilibrio insuportável em desfavor dos particulares. Em outras palavras, os eventuais benefícios trazidos pela ampliação do prazo da rescisória para o Poder Público não justificariam tamanho grau de sacrifício imposto aos particulares, em uma resposta negativa ao teste de proporcionalidade em sentido estrito.

Interessante notar que o acórdão, ao dar pela inconstitucionalidade do dispositivo, faz questão de mencionar que a decisão era fundada nos princípios da isonomia, da razoabilidade, da proporcionalidade e da supremacia do interesse público. $\mathrm{O}$ interesse público, na espécie, recomendava a preservação da isonomia formal, em resguardo dos interesses dos particulares, e não a chancela automática e apriorística da prerrogativa do Poder Público. Ademais, o juízo cognitivo pelo qual esse interesse público foi alcançado percorreu o iter do postulado da proporcionalidade, que buscou realizar uma ponderação entre os interesses em jogo, e não uma mera identificação do interesse público com o interesse estatal. Resta comprovado, assim. que não há prevalência a priori do coletivo sobre o individual, nem do estatal sobre o particular.

\section{IV.3. A Proporcionalidade e as Normas Restritivas de Direitos Individuais}

Um outro conjunto de poderes da Administração Pública comumente associado à idéia de supremacia do interesse público sobre interesses privados são aqueles manejados na restrição de direitos individuais em prol de necessidades ou aspirações da coletividade. Tal atividade restritiva do Estado, que envolve o Legislativo e se concretiza no Executivo, é tradicionalmente chamada de poder de polícia.

$\mathrm{Na}$ lição da doutrina abalizada, o poder de polícia se exerce como em um ciclo - chamado ciclo de polícia ${ }^{60}$ - que (i) principia com a previsão legislativa da restrição à liberdade individual, (ii) passa pelo condicionamento do exercício da liberdade ao consentimento da Administração, (iii) sujeita os particulares à fiscali-

60 V. Diogo de Figueiredo Moreira Neto, Curso de Direito Administrativo, 2001, p. 388. 
zação dos agentes públicos e, por fim, em caso de infringência à disciplina legal, (iv) culmina com a aplicação de sanções administrativas.

Todo esse iter costuma ser explicado a partir da premissa da superioridade do interesse coletivo, promovido pelo Estado, sobre os interesses individuais dos particulares. Tal explicação é, como já antecipado, de todo inconsistente.

As restrições administrativas a direitos fundamentais não podem ser compreendidas hodiernamente senão como uma emanação dos sistema de princípios e valores constitucionais, que admite a compressão de direitos individuais em prol de outros direitos e interesses, de natureza individual ou metaindividual, também contemplados na Lei Maior. O ponto de partida da Constituição brasileira de 1988 é, todavia, a proteção da dignidade humana, em torno da qual erige o edifício normativo dos direitos fundamentais. Entender e justificar as restriçôes administrativas a tais direitos pressupõe conhecer os fundamentos e a lógica de funcionamento desse edifício.

Assim como a Lei Fundamental de Bonn (1949), a Constituição portuguesa (1976) e a Constituição espanhola (1978), a Constituição brasileira de 1988 conferiu importância destacada ao elenco de direitos fundamentais. Contemplados, lá como aqui, logo em capítulo inicial da Carta, os direitos fundamentais são dotados de eficácia imediata (art. $5^{\circ}, \S 1^{\circ}$ ) e protegidos contra eventuais ameaças de supressão ou severo comprometimento, ainda quando tais ameaças advenham de emenda à Constituição (art. 60, $\S 4^{\circ}$, IV).

Em sua concepção clássica, os direitos fundamentais são direitos de defesa, protegendo posições subjetivas contra a intervenção do Poder Público, seja pelo não impedimento à prática de determinado ato, seja pela não-intervenção em situações subjetivas ou pela não-eliminação de posições jurídicas. ${ }^{61}$ No primeiro caso, ter-se-ia o exemplo da liberdade de locomoção, enquanto, no segundo, poder-se-ia cogitar da proteção do direito adquirido contra leis posteriores.

De outro lado, os direitos fundamentais se apresentam como direitos a prestações positivas, tanto de natureza concreta e material, como de natureza normativa. ${ }^{62}$ Assim, v.g., o direito de ir e vir pressupõe um conjunto de atividades do Poder Público (polícia de segurança pública, polícia administrativa) destinadas a preserválo. Já a proteção constitucional do direito de propriedade (e, também, de propriedade intelectual), por exemplo, não teria qualquer sentido sem a existência de um arcabouço de normas legais que lhe conferem a tônica e definem seus contornos.

Nada obstante isso, as normas constitucionais definidoras de direitos fundamentais remetem, não raro, à lei, que poderá instituir restrições ao âmbito de proteção de tais direitos. De acordo com a doutrina especializada, essas restrições podem ser da seguinte ordem: (I) restrições sujeitas à reserva de lei simples; (II) restrições sujeitas à reserva de lei qualificada; e (III) restrições imanentes ou implícitas. ${ }^{63}$

61 Gilmar Ferreira Mendes, Direitos Fundamentais e Controle de Constitucionalidade, Celso Bastos Editor, 1998, p. 32/33.

62 J.J. Gomes Canotilho, Direito Constitucional e Teoria da Constituição, Editora Almedina, 1991, p. 549.

63 V., sobre o tema, Suzana de Toledo Barros, O Princípio da Proporcionalidade e o Controle de 
Tem-se reserva legal simples quando a norma constitucional cinge-se a exigir que eventual restrição a direito fundamental seja prevista em lei, como ocorre com a proteção aos locais de culto e suas liturgias (art. $5^{\circ}$, VI). Já a reserva legal qualificada desponta nos casos em que a norma constitucional não apenas reclama que a restrição se perfaça por meio de lei, mas também estabelece os fins a serem necessariamente perseguidos ou os meios a serem compulsoriamente adotados pelo legislador. Tal é o caso da liberdade de exercício profissional (art. $5^{\circ}$, XIII) e do sigilo de correspondência (art. $5^{\circ}$, XII). No primeiro caso, a lei só pode estabelecer restrições atinentes a qualificaçōes profissionais. No segundo caso, as restrições legais ao sigilo devem se ater aos fins de investigação criminal ou instrução processual penal. Cuida-se aqui, portanto, de uma vinculação constitucional do legislador, tanto de forma (reserva de lei), como de conteúdo (definição prévia dos meios e fins).

Há, ademais, um conjunto de restrições imanentes ou implícitas à própria sistemática constitucional. Tais restrições, embora não expressamente contempladas na norma definidora do direito fundamental, decorrem do princípio da unidade da Constituição, que emergem como condição de harmonização e concordância prática entre os diversos direitos fundamentais e princípios jurídicos contemplados na Lei Fundamental. ${ }^{64}$ Qualquer interferência legislativa nesta seara deve buscar sempre uma solução otimizadora que prestigie, igualmente, todos os direitos ou princípios constitucionais envolvidos. ${ }^{65}$ Tal solução é alcançada pela técnica da ponderação, guiada pelo principio da proporcionalidade.

Aliás, em qualquer uma das três hipóteses acima aventadas (reserva legal simples, reserva legal qualificada e restrição imanente), toda e qualquer limitação a direitos fundamentais deve ser justificada à luz do princípio da proporcionalidade. Com efeito, é o emprego de tal princípio que auxilia o intérprete e aplicador do direito a alcançar a justa proporção na ponderação entre os valores constitucionais envolvidos na limitação a qualquer direito fundamental.

Deste modo, toda e qualquer atividade de polícia, restritiva de algum direito fundamental, só será legítima quando puder ser reconduzida ao sistema constitucional, no qual o Poder Público - seja ele o Estado Legislador, seja o Estado Administrador - encontre fundamento para a proteção e promoção de um outro direito fundamental ou de interesses da coletividade como um todo.

Há situações, entretanto, em que o próprio constituinte antecipou o juízo de ponderação entre interesses individuais e coletivos, dispondo sobre como os conflitos devem ser tratados. Tal foi o caso, v.g., do potencial conflito entre o direito de propriedade e o interesse da coletividade em ver realizadas determinadas obras públicas ou obter determinados serviços públicos, cuja concretização depende da

Constitucionalidade das Leis Restritivas de Direitos Fundamentais, Ed. Brasília Jurídica, 1996, p. 162 e segs.

64 V. Raquel Denize Stumm, Princípio da Proporcionalidade no Direito Constitucional Brasileiro, Livraria do Advogado, 1995, p. 142/145.

65 Suzana Toledo Barros, ob. cit., p. 166. 
expropriação de bens particulares. Antecipando-se ao legislador e ao administrador, o constituinte, ao tempo em que assegurava o direito de propriedade, dispôs que a desapropriação era possível. desde que à contrapartida do pagamento de uma indenização justa, prévia e em dinheiro. O caso não é de prevalência absoluta de um interesse da coletividade sobre o interesse particular - como seria a permissão do simples confisco - mas de uma acomodação entre os dois, mediante adoção de uma solução intermediária, pela qual ambos os interesses são preservados em alguma medida, sem a supressão total de qualquer deles.

De ordinário, contudo, a Constituição apenas admite, explícita ou implicitamente, a restrição a direitos como condição da subsistência de outros direitos e interesses, individuais ou coletivos. Assim, por exemplo. a norma prevista no art. 30, inciso VIII, que confere aos Municípios competência para promover o adequado ordenamento territorial, mediante planejamento e controle do uso, do parcelamento e da ocupação do solo urbano. Caberá, assim, à lei municipal e às Administrações Públicas municipais instituir normas e praticar atos com vistas a compatibilizar o direito de propriedade com o interesse da coletividade na adequada ocupação do solo urbano. A sujeição dos proprietários a certas limitações administrativas - a altura dos edifícios. l'.g. - constitui o resultado de um juízo ponderativo do Poder Público voltada a compatibilizar o direito de propriedade com o zoneamento urbano. $\mathrm{O}$ interesse público, na espécie, consiste na intervenção administrativa que preserva e promove, ao mesmo tempo, ambos os interesses constitucionalmente relevantes.

Na maioria dos casos, todavia, nem a Constituição nem a lei realizam o juízo de ponderação, por completo, entre os interesses conflitantes. Aqui, tal como o legislador, incumbirá ao administrador público percorrer as etapas de adequação, necessidade e proporcionalidade em sentido estrito para encontrar o ponto arquimediano de justa ponderação entre direitos individuais e metas coletivas.

No domínio do direito econômico, por exemplo, há inúmeras circunstâncias em que as decisões administrativas devem procurar compatibilizar o direito do empresário à propriedade privada e à liberdade econômica e os interesses difusos da coletividade na preservação de um meio ambiente equilibrado. Entre soluções igualmente adequadas à preservação do meio ambiente, deve a autoridade administrativa ambiental optar pela medida menos gravosa aos direitos individuais do empresário. Com efeito, a instalação de filtros nas chaminés da fábrica, por constituir-se em solução menos onerosa ao particular, tem preferência sobre a importação de novo maquinário que emita menor quantidade de gases no processo industrial. Mesmo numa outra hipótese, em que o maquinário importado fosse, de fato, um pouco menos poluente, a solução mais proporcional seria a instalação dos filtros, diante de uma abissal disparidade de preços entre os dois equipamentos. No juízo de custo-benefício (proporcionalidade em sentido estrito), a balança penderia em favor do empresário.

Também aqui, ao contrário de uma regra de prevalência absoluta, tem-se a aplicação do postulado da proporcionalidade, que busca alcançar um ponto de otimização entre os interesses conflitantes no processo de construção da decisão administrativa. Nesta, como em diversas situações, a promoção do interesse público inclui em seu bojo a preservação otimizada do direito individual vis-à-vis dos interesses difusos da sociedade. 


\section{Conclusão}

Ao longo do presente ensaio, pretendeu-se demonstrar que a origem liberal e garantística do direito administrativo, forjado a partir de uma milagrosa submissão da burocracia estatal à lei e aos direitos individuais, não passa de um mito. Passados dois séculos da sua gênese, é possível constatar que a construção teórica do direito administrativo não se deveu nem ao advento do Estado de Direito, nem à afirmação história do princípio da separação dos poderes.

Com efeito, havendo sido produto da elaboração jurisprudencial do Conselho de Estado francês, as categorias básicas da disciplina não surgiram da sujeição da Administração à vontade heterônoma da lei, mas antes de uma autovinculação do Poder Executivo à sua própria vontade. Por outro lado, a adoção da jurisdição administrativa, paralela e infensa à jurisdição comum, rendeu ensejo à imunização do Poder Executivo dos controles dos demais Poderes e, principalmente, do controle do cidadão. O modelo administrativo francês, no qual a burocracia legisla para si e julga a si mesma, não pode ser considerado fruto, mas a própria antítese da idéia de separação de poderes.

Neste contexto, é correto afirmar que a dogmática administrativista estruturou-se a partir de premissas teóricas comprometidas com a preservação do principio da autoridade, e não com a promoção das conquistas liberais e democráticas. O direito administrativo, nascido da superação histórica do Antigo Regime, serviu como instrumento retórico para a preservação daquela mesma lógica de poder.

Uma das categorias forjadas desde essa origem autoritária foi o chamado princípio da supremacia do interesse público sobre o interesse particular. Embora decantado pela literatura brasileira como fundamento e princípio normativo do direito administrativo, sua inconsistência teórica e sua incompatibilidade visceral com a sistemática constitucional dos direitos fundamentais são patentes.

Com efeito, uma norma que preconiza a supremacia a priori de um valor, princípio ou direito sobre outros não pode ser qualificado como princípio. Ao contrário, um princípio, por definição, é norma de textura aberta, cujo fim ou estado de coisas para o qual aponta deve sempre ser contextualizado e ponderado com outros princípios igualmente previstos no ordenamento jurídico. A prevalência apriorísitica e descontextualizada de um princípio constitui uma contradição em termos.

Por outra via, a norma de supremacia pressupõe uma necessária dissociação entre $o$ interesse público e os interesses privados. Ocorre que, muitas vezes, a promoção do interesse público - entendido como conjunto de metas gerais da coletividade juridicamente consagradas - consiste, justamente, na preservação de um direito individual, na maior medida possível. A imbricação conceitual entre interesse público, interesses coletivos e interesses individuais não permite falar em uma regra de prevalência absoluta do público sobre o privado ou do coletivo sobre $o$ individual.

$\mathrm{Na}$ verdade, o conceito de interesse público é daqueles ditos juridicamente indeterminados, que só ganham maior concretude a partir da disposição constitucional dos direitos fundamentais em um sistema que contempla e pressupõe restrições ao seu exercício em prol de outros direitos, bem como de metas e aspirações da 
coletividade de caráter metaindividual. igualmente estampadas na Constituição. Ao Estado Legislador e ao Estado Administrador incumbe atuar como intérpretes e concretizadores de tal sistema, realizando as ponderações entre interesses conflitantes, guiados pelo postulado da proporcionalidade.

Assim, o melhor interesse público só pode ser obtido a partir de um procedimento racional que envolve a disciplina constitucional de interesses individuais e coletivos específicos, bem como um juízo de ponderação que permita a realização de todos eles na maior extensão possível. $O$ instrumento deste raciocínio ponderativo é o postulado da proporcionalidade.

Veja-se que não se nega, de forma alguma, o conceito de interesse público, mas tão-somente a existência de um princípio da supremacia do interesse público. Explica-se: se ointeresse público, por ser um conceito jurídico determinado, só é aferível após juízos de ponderação entre direitos individuais e metas ou interesses coletivos, feitos à luz de circunstâncias concretas, qual o sentido em falar-se num princípio jurídico que apenas afirme que, no final, ao cabo do processo ponderativo, se chegará a uma solução (isto é, ao interesse público concreto) que sempre prevalecerá? Em outras palavras: qualquer que seja o conteúdo deste "interesse público" obtido em concreto, ele sempre prevalecerá. Ora, isso não é um princípio jurídico. Um princípio que se presta a afirmar que o que há de prevalecer sempre prevaleceránão é um princípio, mas uma tautologia. Daí se propor que é o postulado da proporcionalidade que, na verdade, explica como se define o que é o interesse público, em cada caso. O problema teórico verdadeiro não é a prevalência, mas o conteúdo do que deve prevalecer.

A preservação, na maior medida possível, dos direitos individuais constitui porção do próprio interesse público. São metas gerais da sociedade política, juridicamente estabelecidas, tanto viabilizar o funcionamento da Administração Pública, mediante instituição de prerrogativas materiais e processuais, como preservar e promover, da forma mais extensa quanto possível, os direitos dos particulares. Assim, esse esforço de harmonização não se coaduna com qualquer regra absoluta de prevalência a priori dos papéis institucionais do Estado sobre os interesses individuais privados.

Como a isonomia, tal como os fins de interesse coletivo cometidos aos Poder Público, também está prevista como norma constitucional, as hipóteses de tratamento diferenciado conferido ao Poder Público em relação aos particulares devem obedecer aos rígidos critérios estabelecidos pela lógica do princípio constitucional da igualdade. É dizer: qualquer diferenciação deve ser instituída por lei, além de sujeitar-se, no seu contexto específico e na sua extensão, ao teste da proporcionalidade. Portanto, para que um privilégio instituído em favor da Administração Pública seja constitucionalmente legítimo, é mister que: (I) a compressão do princípio da isonomia, isto é, a discriminação criada em desfavor dos particulares seja apta a viabilizar o cumprimento pelo Estado dos fins que the foram cometidos pela Constituição ou pela lei; (II) o grau ou medida da compressão da isonomia, isto é, a extensão da discriminação criada em desfavor dos particulares deve observar o limite do estritamente necessário e exigível para viabilizar o cumprimento pelo Estado dos fins que lhe foram cometidos pela Constituição ou pela lei; (III) por fim, o grau ou medida 
do sacrifício imposto à isonomia deve ser compensado pela importância da utilidade gerada, numa análise prognóstica de custos para os particulares e benefícios para a coletividade como um todo.

De outra banda, toda e qualquer atividade de polícia, restritiva de algum direito fundamental, só será legítima quando puder ser reconduzida ao sistema constitucional, no qual o Poder Público - seja ele o Estado Legislador, seja o Estado Administrador - encontre fundamento para a proteção e promoção de um outro direito fundamental ou de interesses da coletividade como um todo.

Há situações em que o próprio constituinte antecipou o juízo de ponderação entre interesses individuais e coletivos, dispondo sobre como os conflitos devem ser tratados. De ordinário, contudo, a Constituição apenas admite, explícita ou implicitamente, a restrição a direitos como condição da subsistência de outros direitos e interesses, individuais ou coletivos. Assim, por exemplo, a norma prevista no art. 30 , inciso VIII, que confere aos Municípios competência para promover o adequado ordenamento territorial, mediante planejamento e controle do uso, do parcelamento e da ocupação do solo urbano. Caberá, assim, à lei municipal e às Administrações Públicas municipais instituir normas e praticar atos com vistas a compatibilizar o direito de propriedade com o interesse da coletividade na adequada ocupação do solo urbano. A sujeição dos proprietários a certas limitações administrativas - a altura dos edifícios, v.g. - constitui o resultado de um juízo ponderativo do Poder Público voltada a compatibilizar o direito de propriedade com o zoneamento urbano. O interesse público, na espécie, consiste na intervenção administrativa que preserva e promove, ao mesmo tempo, ambos os interesses constitucionalmente relevantes.

Na maioria dos casos, todavia, nem a Constituição nem a lei realizam o juízo de ponderação, por completo, entre os interesses conflitantes. Aqui, tal como o legislador, incumbirá ao administrador público percorrer as etapas de adequação, necessidade e proporcionalidade em sentido estrito para encontrar o ponto arquimediano de justa ponderação entre direitos individuais e metas coletivas. 




0 Direito Internacional Privado acompanha os grandes ramos do direito nas suas dimensões internacionais, que se materializam sempre que as relaçōes humanas têm conexāo com mais de um sistema jurídico, nacional ou pessoal. Este volume é dedicado às questões referentes ao matrimônio - casamento e divórcio - na sua dimensão internacional, entrentando toda a multiplicidade de problemas que se impõem nesta seara.

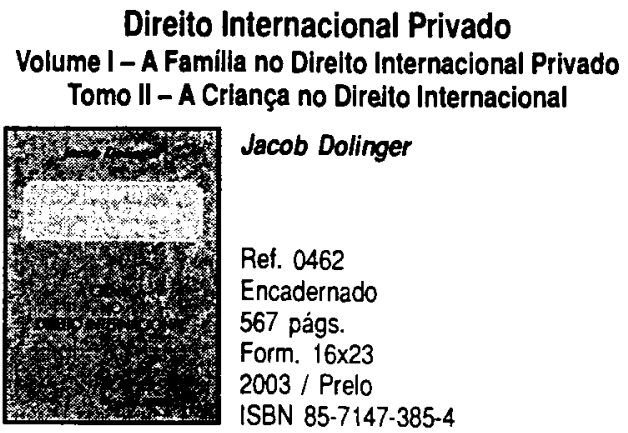

Este não é um estudo centrado apenas nas relações entre pais efilhos, ele abrange, de forma mais ampla, os direitos da criança, sua posição no direito internacional, no seu sentido total. Esta perspectiva nova não se divorcia muito do prisma clássico, pois em determinadas circunstâncias ocorre o encontro da solução do conflito das leis com a proteção à criança.

\section{Direito Internacional Privado \\ Arbitragem Comercial Internacional}



Jacob Dolinger / Carmem Tiburcio

Ref. 0468

Encadernado

1078 págs.

2003

Form. $16 \times 23$

ISBN: $85-7147 \cdot 397 \cdot 8$

É dividido em três partes: doutrina, jurisprudência comparada e comentada e legislação. Parte I: questões fundamentais, antecedentes históricos e desenvolvimento da arbitragem no Brasil. Parte II: 19 temas polêmicos, que têm sido debatidos perante tribunais arbitrais, tribunais estatais estrangeiros e tribunais brasileiros. Parte III: legislação brasileira sobre a matéria, atual e pretérita, legislaçāo de arbitragem de países com os quais o Brasil mantém relações comerciais.

\section{Direito Internacional Privado Parte Geral}

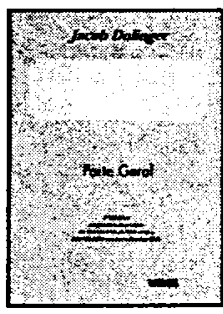
Jacob Dolinger

Ref. 0056

Encadernado

552 págs.

Form. $16 \times 23$

$2003 / 7^{2} \mathrm{ed}$

ISBN 85-7147-366-8

As múltiplas relações privadas internacionais, no campo do direito civil, comercial e processual, relacionadas com sistemas jurídicos diversos e muitas vezes divergentes, são disciplinadas pelo sobredireito espacial, que formula um complexo de regras e princípios para orientar 0 aplicador da lei na escolha do sistema jurídico adequado para determinada situação ou relação jurídica. A presente obra concentra-se na parte geral da ciência. 